\title{
SCIDiC
}

International Journal of Dentistry and Oral Science (IJDOS)

ISSN: 2377-8075

\section{Clinical Practical Guidelines On Minimally Invasive Endodontics}

Review Article

Swathi UB ${ }^{1}$, Sindhu Ramesh ${ }^{2 *}$, Pradeep.S $S^{3}$

\begin{abstract}
${ }^{1}$ Department of Conservative Dentistry and Endodontics, Saveetha Dental College and Hospitals, Saveetha Institute of Medical and Technical Sciences, Saveetha University, Chennai, India.

${ }^{2}$ Professor, Department of Conservative Dentistry and Endodontics, Clinical Genetics Lab, Saveetha Dental College and Hospitals, Saveetha Institute of Medical and Technical Sciences, Saveetha University, Chennai - 600077, India.

${ }^{3}$ Reader, Department of Conservative Dentistry and Endodontics, Clinical Genetics Lab, Saveetha Dental College and Hospitals, Saveetha Institute of Medical and Technical Sciences, Saveetha University, Chennai - 600077, India.
\end{abstract}

\section{Abstract}

This review comprises various methods of minimally invasive treatment approaches along with traditional approaches that are used in Endodontics.Searches were based on MEDLINE, PubMed databases and bibliographies of all relevant articles and textbooks. The main focus should be on perpetual preservation of what remains rather than meticulous replacement of what is missing which is achieved by the form extension for prevention to the minimal invasion. Minimally invasive approach requiresknowledge about the root canal anatomy,diagnosis,decision making, along with preservation of structural integrity of tooth, alternate access designs,image guided endodontic access, dynamically guided endodontic access, microguided endodontic access, modern bur designs, cleaning and shaping, 3D irrigation and disinfection, root strengthening and magnification aids like the loupes and surgical operative microscope.With the help of the following methods mentioned in this article one can preserve the structural integrity of the tooth with minimal invasion and maximum appropriateness.

Keywords: Dynamically Guided Endodontic Access; Image Guided Endodontic Access; Magnification; Micro Guidedendodontic Access; Minimally Invasive Endodontics.

\section{Introduction}

The objective of root canal treatment is to eliminate microorganisms and pathologic debris from the root canal system,to seal the root canal three dimensionally and to prevent any reinfection [1]. Herbert Schielder in 1974, listed certain mechanical objectives of cleaning and shaping to promote the success of the root canal therapy. During root canal therapy,with the aim of eliminating the microorganisms pathologic debris from the root canal system one should also make sure that there is no extensive loss of tooth structure during the process.Correct diagnosis ,decision making, minimal access openings depending on anatomical challenges,minimal removal of dentin, cleaning and shaping of the root canal by retaining as much sound dentin as possible,performing a crown lengthening procedures to establish sound tooth margins for core/crown restorations rather than planning for a tooth extraction and implant or bridge placement helps in preserving the structural integrity of the tooth structure. [2-7]. Previously our team has a rich experience in working on various research projects across multiple disciplines [8-22] Now the growing trend in this area motivated us to pursue this project.

The article lists out a few approaches of Minimally Invasive Endodontics (MIE) which can preserve the structural integrity of the tooth with minimal invasion and maximum appropriateness.

\section{Diagnosis And Treatment Planning}

Many factors favor caries progression such as endodontic and restorative factors and should be considered while treating caries lesions [23-26]. Proper endodontic diagnosis plays an important role for the success of treatment [27-29]. Mature teeth with irreversible pulpitis or apical periodontitis require root canal treatment,during which excessive loss of dental hard tissue can

\section{*Corresponding Author}

Sindhu Ramesh,

Professor, Department of Conservative Dentistry and Endodontics, Clinical Genetics Lab, Saveetha Dental College and Hospitals, Saveetha Institute of Medical and Technical Sciences, Saveetha University, Chennai - 600077, India.

Tel: 9840136543

E-mail: sindhuramesh@saveetha.com

Received: May 03, 2021

Accepted: July 29, 2021

Published: August 02, 2021

Citation: Swathi UB, Sindhu Ramesh, Pradeep.S. Clinical Practical Guidelines On Minimally Invasive Endodontics. Int J Dentistry Oral Sci. 2021;8(8):3601-3606. doi: http://dx.doi.org/10.19070/2377-8075-21000737

Copyright: Sindhu Ramesh 2021 . This is an open-access article distributed under the terms of the Creative Commons Attribution License, which permits unrestricted use, distribution and reproduction in any medium, provided the original author and source are credited. 
lead to weakening the tooth and thus more prone to fracture.[30] Clinical research on vital pulp therapy provides more options for new biologically driven treatment protocols.[31] Minimally invasive endodontics treatment modalities include preservation and maintaining physiological and defensive functions along with minimal removal of hard tissue which preserves structural integrity of tooth.Avoiding full pulpectomies which involves complete removal of the pulp to the apical constriction,wherever possible the biological response of immune system could be enhanced by even a partially retained pulp thus improving the treatment outcome and also helps in preventing further infection of the apical area.A study done by Seltzer \& Bender 1963,Garfunkel et al. 1973, Dummer et al. 1980 stated that conventional treatment approaches was thought to have a poor relationship between the histological state of the pulp and clinical signs and symptoms in mature teeth,[32] the recent histological study have shown that there is a good correlation between clinical symptoms of pulpitis and the histological state of a diseased pulp.[33]

Irreversible pulpitis cases have shown morphological changes indicating presence of inflammation or necrosis of coronal pulp while the radicular pulp is viable.This paves way of preserving radicular pulp thus preventing the need for a pulpectomy.This minimally invasive treatment approach is called the Endolight, [31] and helps in preservation of the immunological functions and retaining the structural integrity of tooth simplify treatment procedures and to avoid treatment complications related with the varying root canal anatomy, reduce cost and inconvenience of patients and the society and is a less painful procedure.[34]

Newer proposal for pulp diagnosis and related treatment modalities

New proposals have been advocated for pulpal diagnosis and re- lated treatment modalities.[35-37] (Figure 1)

\section{Structural Integrity Of Tooth}

Remaining structural integrity of the tooth is an important factor that determines the prognosis as it relates to the post endodontic survival rate of the tooth. Maintenance of strength along with stiffness that resists structural deformation becomes the goal of all restorative procedures, mainly in endodontics.

A study compared the impact of endodontic versus restorative procedures on tooth strength and they found that endodontic access openings by themselves have only $5 \%$ impact on tooth stiffness in comparison to any restorative preparation that removes the tooth's marginal ridges which also reduces the cuspal stiffness by $63 \%$. Marginal ridges are a key factor in retaining the strength of the tooth. Widely held clinical perception is that endodontically treated teeth are more brittle and hence they are more vulnerable to fracture. Endodontic treatment is the major etiologic factor for tooth fracture, Brittleness of teeth due to loss of moisture, [38] insignificant difference in the moisture content between endodontically treated teeth and teeth with vital pulp. [39]

More Emphasis has been given on the importance of conserving the bulk of dentine to maintain the structural integrity of postendodontically restored teeth. When endodontically treated teeth fail under function, that outcome is determined by two etiologiessuch as degree of stress experienced by the tooth when under load and Inherent biomechanical properties of the remaining structure responsible for resisting the fracture.

Attempts made to prevent fracture rates are by Preservation of peri cervical dentin,3D ferrule and 3D soffit.[40]Figure 2)(Figure 3)

Figure 1. Represents Flowchart showing strategies for pulpal diagnosis and treatment planning.

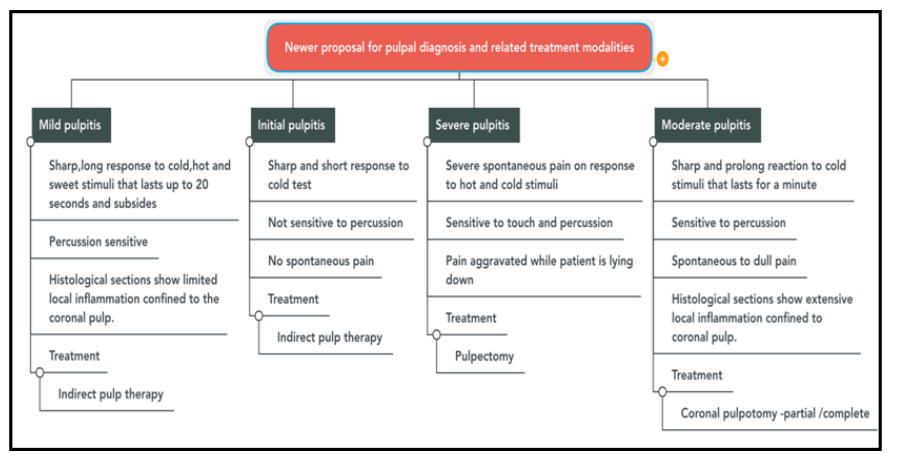

Figure 2. Represents Methods To Prevent Fracture Rate.

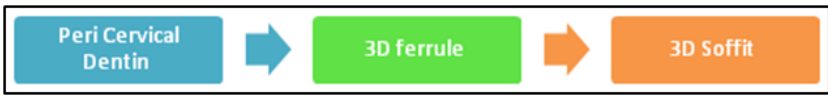

Figure 3. Represents Flowchart Explaining Pericervical Dentin,3D Ferrule And 3D Soffit.

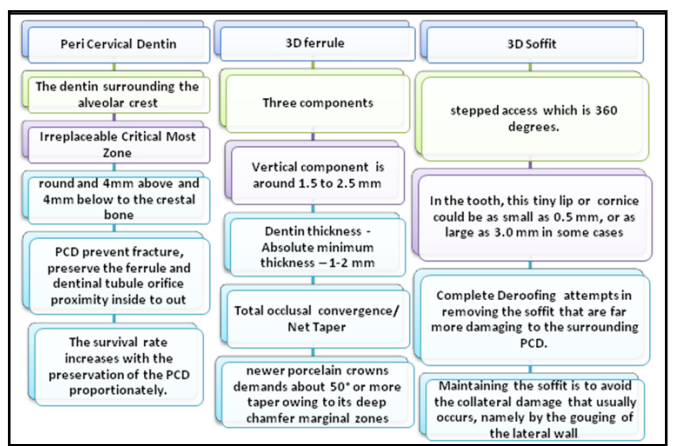




\section{Alternate Access Designs}

Traditional access designs (TECs) aim at a straight line access into the root canals which increases the biomechanical preparation efficacy and also helps in reducing the procedural errors. New instruments have round-ended tapers that help to increase the radii of the gouges and nicks that can act as stress concentration points. The flat sides help to create smoother, flatter walls and minimize gouges.Newer access designs include Conservative Endodontic Access Cavity, Ninja Endodontic Access Cavity Orifice-Directed Dentin Conservation Access Cavity/Truss Access Cavity, Incisal Access, Cala Lilly Enamel Preparation and Caries driven Access. [41](Table 1)

CECs, TECs and NECs found that TECs presented lower fracture strength than CECs and NECs in maxillary and mandibular premolars and molars and no statistical significance was found in the fracture resistance mean values of CECs and NECs.[42]

Conservative endodontic access was associated with the risk of compromised canal instrumentation only in the molar distal canals, and it conserved coronal dentin and has a benefit of increased fracture resistance in both the mandibular molars and premolars. [43] Traditional endodontic access may lead to a better preservation of the original canal anatomy during shaping compared with conservative,at the apical level.[44] Instrumentation efficacy and biomechanical responses in conservative and traditional preparations in maxillary molars and found that there was no significant difference. [45] The MB2 detection rate of CEC (53.3\%) and TEC $(60 \%)$ are higher than that of statistically that of NEC (\%31.6). There was no significant difference between CEC and TEC in terms of determining the MB2 canals.[46] No significant difference was seen in the fracture strengths of teeth prepared using the TEC and CEC methods, the types of fractures were less serious with CEC preparation. [47] Both traditional and conservative access designs have their own pros and cons as concentrating on too many conservative designs can lead to inefficient cleaning and shaping and also inability to get the extra canals can in turn lead to failure of the treatment.[48] Hence, one must know when to use based on the right tooth and situation in order to avoid failures. Various other means of conserving the tooth structure through a minimal invasive approach include the use of image guided endodontic access,dynamically guided access,micro guided access and the use of modern endodontic burs.[49](Figure 4)

\section{Cleaning And Shaping}

Negotiating and a complete shaping of the canal is the primary goal. A 3D cleaning and shaping ensures minimal mechanical shaping and thorough an irrigation protocol.[50-53].Combination of mechanical instrumentation, use of irrigating solutions and intracanal medicaments should be used to remove and dissolve organic and inorganic debris,remove the smear layer and maintain dentin permeability.[54] Important things to be included during cleaning and shaping are: Small apical terminal diameters but wide tapers apically, while ensuring sufficient dentin remaining within the body of the root canal. Studies vary on which size diameter

Table 1. Represents Alternate Access Cavity Designs.

\begin{tabular}{|c|c|c|c|c|c|}
\hline \multicolumn{6}{|c|}{ ALTERNATIVE ACCESS DESIGNS } \\
\hline $\begin{array}{c}\text { Conservative } \\
\text { Endodontic Access } \\
\text { Cavity (CECs) } \\
\end{array}$ & $\begin{array}{l}\text { Ninja Endodon- } \\
\text { tic Access Cavity } \\
\text { (NECs) }\end{array}$ & $\begin{array}{c}\text { Orifice-Directed Dentin } \\
\text { Conservation Access } \\
\text { Cavity/'Truss' Access }\end{array}$ & Incisal Access & $\begin{array}{l}\text { Cala Lilly Enamel } \\
\text { Preparation }\end{array}$ & $\begin{array}{c}\text { Caries driven } \\
\text { access }\end{array}$ \\
\hline $\begin{array}{l}\text {-Developed by John } \\
\text { Khademi and David } \\
\text { Clark }\end{array}$ & $\begin{array}{l}\text {-An access with a } \\
\text { Ninja outline, the } \\
\text { oblique projection } \\
\text { is towards the cen- } \\
\text { tral fossa of the } \\
\text { root orifices in an } \\
\text { occlusal plane. }\end{array}$ & $\begin{array}{l}\text {-Purpose -preserve the } \\
\text { dentin by leaving a truss } \\
\text { of dentin between the } \\
\text { two cavities that has been } \\
\text { prepared. }\end{array}$ & $\begin{array}{l}\text {-Blind Tunnelling: Gouging } \\
\text { is observed with round } \\
\text { burs which are aggressive in } \\
\text { nature and cingulum access. } \\
\text { Buccal-lingual gouging (not } \\
\text { easily seen in x-rays) occurs } \\
\text { in almost every traditional- } \\
\text { ly-accessed case. }\end{array}$ & $\begin{array}{l}\bullet \text { Unfavourable } \mathrm{C} \\
\text { factor and poor enamel } \\
\text { rod engagement are } \\
\text { typically present when } \\
\text { removing old amal- } \\
\text { gam or composite } \\
\text { restorations or with } \\
\text { traditional endodontic } \\
\text { access } 90 \text { degree to the } \\
\text { occlusal table }\end{array}$ & \multirow{3}{*}{$\begin{array}{l}\text { - Caries driven } \\
\text { access is made } \\
\text { either through } \\
\text { the mesial } \\
\text { or distal wall } \\
\text { following the } \\
\text { caries process. }\end{array}$} \\
\hline $\begin{array}{l}\text { - Traditional access } \\
\text { cavities were modi- } \\
\text { fied and developed } \\
\text { into constricted } \\
\text { or conservative } \\
\text { endodontic access } \\
\text { cavities }\end{array}$ & & $\begin{array}{l}\text {-Separate cavities are made } \\
\text { to approach the canals }\end{array}$ & & & \\
\hline $\begin{array}{l}\text { - Minimizes removal } \\
\text { of the tooth struc- } \\
\text { ture while maintain- } \\
\text { ing the mechanical } \\
\text { stability of the tooth } \\
\text { for long-term sur- } \\
\text { vival and function of } \\
\text { the endodontically } \\
\text { treated teeth }\end{array}$ & $\begin{array}{l}\text { - The design is } \\
\text { parallel with the } \\
\text { enamel cut of } 90 \\
\text { or more to the oc- } \\
\text { clusal plane, which } \\
\text { makes it easier } \\
\text { to trace the root } \\
\text { canal orifices from } \\
\text { the varying visual } \\
\text { angulations. }\end{array}$ & $\begin{array}{l}\text { - Mandibular molars, two } \\
\text { separate cavities are made } \\
\text { to approach the mesial and } \\
\text { the distal canals and max- } \\
\text { illary molars, the mesio- } \\
\text { buccal and the distobuccal } \\
\text { cavities is approached in } \\
\text { one cavity and a separate } \\
\text { cavity for the palatal canal } \\
\text { is made. }\end{array}$ & $\begin{array}{l}\text {-Inverse Funnel: As the ac- } \\
\text { cess cavity grows internally, } \\
\text { an inverse funnel is created } \\
\text { and the precious peri-cervi- } \\
\text { cal dentin is lost each time } \\
\text { when the bur enters the } \\
\text { tooth. }\end{array}$ & $\begin{array}{c}\text { 'The enamel is cut } \\
\text { back at } 45 \text { degrees with } \\
\text { the shape of a Cala } \\
\text { Lilly. }\end{array}$ & \\
\hline
\end{tabular}


Figure 4. Represents Various Methods That Can Be Followed To Conserve The Tooth Structure Through A Minimal Invasive Approach.

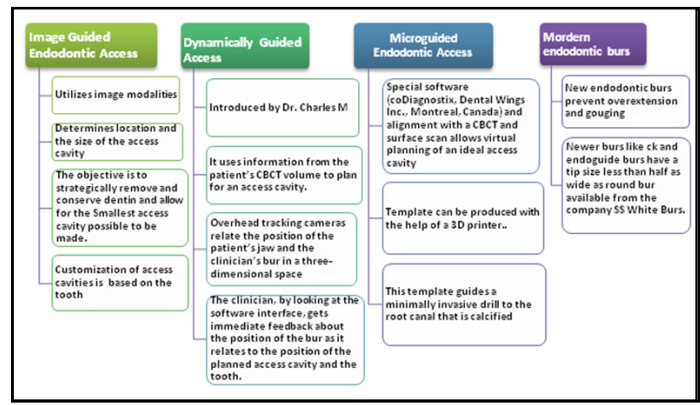

Figure 5. Represents Methods That Enable Minimal Invasiveness and Maximum Effectiveness During Cleaning And Shaping.

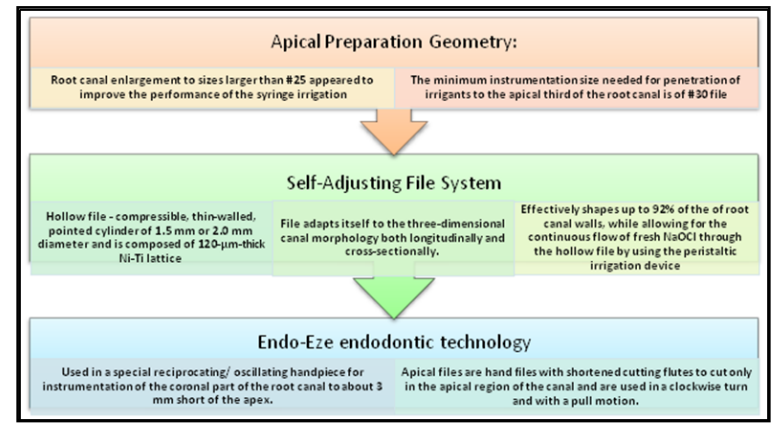

Figure 6. Represents Depicting Various Types of 3D Disinfection that Can Used During Cleaning and Shaping.

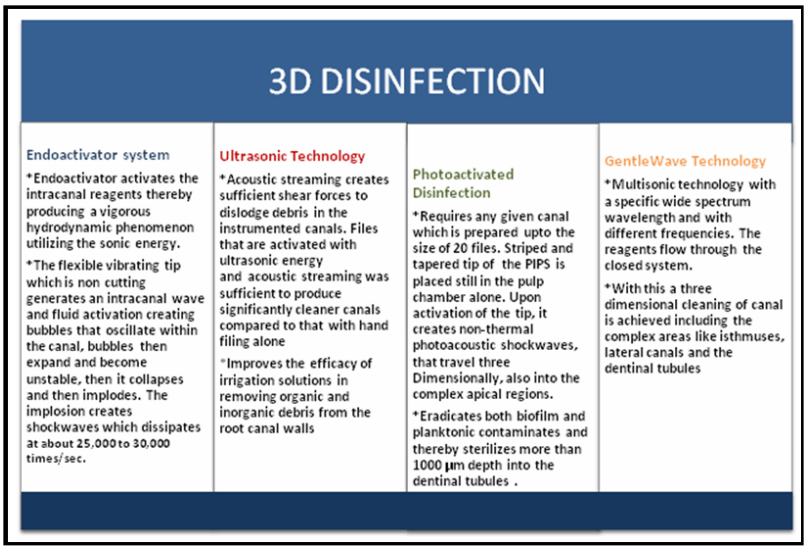

will accomplish the maximum cleaning. Apical overpreparation can cause fracture of tooth as it weakens tooth structure.Apical preparation geometry [55-57], the use of self adjusting file [58], the use of Endo-Eze technology, [59] 3D disinfection by means of endoactivator system,ultrasonics, [60] photoactivated disinfection and the use of gentle wave technology [61] are various means by which minimal invasiveness and maximum effectiveness can be achieved.(Figure 5)(Figure 6)

\section{Root Strengthening}

Minimally invasive therapy directs the usage of posts in the endodontically treated teeth .Tooth structure is more valuable than the use of a post in every circumstance where adequate structure exists for a ferrule.[62] Adhesive materials can be used and are minimally invasive.

Posts: Traditional post space preparation resulted in excessive tooth preparation with the use of peeso reamers which in turn leads to loss of structural integrity of the tooth. The use of newer posts like Ribbond and Everstick increases the flexibility and requires minimal tooth preparation. Fibre-reinforced resin posts provide a more elastic support to the core.

\section{Magnification}

Magnification magnifies the look in endodontics to the extent that one sees it clearer which has made it possible to look through the difficulties of the root canal treatment. The resolution of the human eye is around $0.2 \mathrm{~mm}$. This can be enhanced upto 6 micrometre with the help of a Surgical Operative Microscope.[63] Surgical microscopes are no longer a luxury but it is a necessity in the field of dental practice.

Our institution is passionate about high quality evidence based research and has excelled in various fields. [12, 64-73] The tooth structure has a great influence on fracture resistance of the tooth. This aspect has led us to focus on this current research.

\section{Conclusion}

Minimally invasive endodontics helps in preserving the tooth 
structure and requires optical magnification aids (surgical microscope), ultrasonic-assisted preparation techniques, modern file systems, and in-depth knowledge of the tooth and the root canal anatomy and is in the interest of the patient.The clinician should strike the right balance between minimal preparation and the traditional endodontic preparation with their own pros and cons and thus achieve the objectives of endodontic treatment.

\section{Acknowledgement}

With Sincere gratitude,we acknowledge the staff members of the department of Conservative Dentistry and Endodontics, Saveetha Dental College for their extended support towards the completion of research.

\section{References}

[1]. Nair PR. Pathogenesis of apical periodontitis and the causes of endodontic failures. Crit Rev Oral Biol Med. 2004 Nov; 15(6):348-81.

[2]. Jenarthanan S, Subbarao C. Comparative evaluation of the efficacy of diclofenac sodium administered using different delivery routes in the management of endodontic pain: A randomized controlled clinical trial. J Conserv Dent. 2018 May-Jun;21(3):297-301.Pubmed PMID: 29899633.

[3]. Nandakumar M, Nasim I. Comparative evaluation of grape seed and cranberry extracts in preventing enamel erosion: An optical emission spectrometric analysis. J Conserv Dent. 2018 Sep-Oct;21(5):516-520.Pubmed PMID: 30294113.

[4]. Malli Sureshbabu N, Selvarasu K, V JK, Nandakumar M, Selvam D. Concentrated Growth Factors as an Ingenious Biomaterial in Regeneration of Bony Defects after Periapical Surgery: A Report of Two Cases. Case Rep Dent. 2019 Jan 22;2019:7046203.Pubmed PMID: 30805222.

[5]. Teja KV, Ramesh S, Priya V. Regulation of matrix metalloproteinase-3 gene expression in inflammation: A molecular study. J Conserv Dent. 2018 Nov;21(6):592-6.

[6]. Rajakeerthi R, Nivedhitha MS. Natural Product as the Storage medium for an avulsed tooth-A Systematic Review. Cumhur. Dent. J. 2019 Jun $11 ; 22(2): 249-56$.

[7]. Rajendran R, Kunjusankaran RN, Sandhya R, Anilkumar A, Santhosh R, Patil SR. Comparative evaluation of remineralizing potential of a paste containing bioactive glass and a topical cream containing casein phosphopeptide-amorphous calcium phosphate: An in vitro study. Pesqui. Bras. Odontopediatria Clín. Integr. 2019 Oct 10;19:1-10.

[8]. Govindaraju L, Gurunathan D. Effectiveness of Chewable Tooth Brush in Children-A Prospective Clinical Study. J Clin Diagn Res. 2017 Mar;11(3):ZC31-ZC34.Pubmed PMID: 28511505.

[9]. Christabel A, Anantanarayanan P, Subash P, Soh CL, Ramanathan M, Muthusekhar MR, et al. Comparison of pterygomaxillary dysjunction with tuberosity separation in isolated Le Fort I osteotomies: a prospective, multi-centre, triple-blind, randomized controlled trial. Int J Oral Maxillofac Surg. 2016 Feb;45(2):180-5.Pubmed PMID: 26338075

[10]. Soh CL, Narayanan V. Quality of life assessment in patients with dentofacial deformity undergoing orthognathic surgery--a systematic review. Int J Oral Maxillofac Surg. 2013 Aug;42(8):974-80.Pubmed PMID: 23702370.

[11]. Mehta M, Deeksha, Tewari D, Gupta G, Awasthi R, Singh H, et al. Oligonucleotide therapy: An emerging focus area for drug delivery in chronic inflammatory respiratory diseases. Chem Biol Interact. 2019 Aug 1;308:206215.Pubmed PMID: 31136735.

[12]. Ezhilarasan D, Apoorva VS, Ashok Vardhan N. Syzygium cumini extract induced reactive oxygen species-mediated apoptosis in human oral squamous carcinoma cells. J Oral Pathol Med. 2019 Feb;48(2):115-121.Pubmed PMID: 30451321

[13]. Campeau PM, Kasperaviciute D, Lu JT, Burrage LC, Kim C, Hori M, et al. The genetic basis of DOORS syndrome: an exome-sequencing study. Lancet Neurol. 2014 Jan;13(1):44-58.Pubmed PMID: 24291220.

[14]. Sneha S. Knowledge and awareness regarding antibiotic prophylaxis for infective endocarditis among undergraduate dental students. Asian J Pharm Clin Res. 2016 Oct 1:154-9.

[15]. Christabel SL, Linda Christabel S. Prevalence of type of frenal attachment and morphology of frenum in children, Chennai, Tamil Nadu. World J Dent. 2015 Oct;6(4):203-7.

[16]. Kumar S, Rahman R. Knowledge, awareness, and practices regarding biomedical waste management among undergraduate dental students. Asian J
Pharm Clin Res. 2017;10(8):341.

[17]. Sridharan G, Ramani P, Patankar S. Serum metabolomics in oral leukoplakia and oral squamous cell carcinoma. J Cancer Res Ther. 2017 Jul 1;13(3):55661.

[18]. Ramesh A, Varghese SS, Doraiswamy JN, Malaiappan S. Herbs as an antioxidant arsenal for periodontal diseases. J Intercult Ethnopharmacol. 2016 Jan 27;5(1):92-6.Pubmed PMID: 27069730.

[19]. Thamaraiselvan M, Elavarasu S, Thangakumaran S, Gadagi JS, Arthie T. Comparative clinical evaluation of coronally advanced flap with or without platelet rich fibrin membrane in the treatment of isolated gingival recession. J Indian Soc Periodontol. 2015 Jan;19(1):66-71.

[20]. Thangaraj SV, Shyamsundar V, Krishnamurthy A, Ramani P, Ganesan K, Muthuswami M, et al. Molecular Portrait of Oral Tongue Squamous Cell Carcinoma Shown by Integrative Meta-Analysis of Expression Profiles with Validations. PLoS One. 2016 Jun 9;11(6):e0156582.Pubmed PMID: 27280700.

[21]. Ponnulakshmi R, Shyamaladevi B, Vijayalakshmi P, Selvaraj J. In silico and in vivo analysis to identify the antidiabetic activity of beta sitosterol in adipose tissue of high fat diet and sucrose induced type-2 diabetic experimental rats. Toxicol Mech Methods. 2019 May;29(4):276-290.Pubmed PMID: 30461321.

[22]. Ramakrishnan M, Shukri M. Fluoride, Fluoridated Toothpaste Efficacy And Its Safety In Children-Review. Int J Pharm Res. 2018 Oct 1;10(04):109-14.

[23]. Poorni S, Srinivasan MR, Nivedhitha MS. Probiotic Streptococcus strains in caries prevention: A systematic review. J Conserv Dent. 2019 Mar;22(2):1238.

[24]. Khandelwal A, Palanivelu A. Correlation between dental caries and salivary albumin in adult population in Chennai: An in vivo study. Braz. Dent. Sci. 2019 Apr 30;22(2):228-33.

[25]. Ramarao S, Sathyanarayanan U. CRA Grid - A preliminary development and calibration of a paper-based objectivization of caries risk assessment in undergraduate dental education. J Conserv Dent. 2019 Mar-Apr;22(2):185-190. Pubmed PMID: 31142991.

[26]. Azeem RA, Sureshbabu NM. Clinical performance of direct versus indirect composite restorations in posterior teeth: A systematic review. J Conserv Dent. 2018 Jan;21(1):2-9.

[27]. Surathu N, Ramesh S. Root canal morphology of maxillary first molars using cone beam computed tomography. IOSR J Dent Med Sci. 2015;14(9):1-4.

[28]. Janani K, Sandhya R. A survey on skills for cone beam computed tomography interpretation among endodontists for endodontic treatment procedure. Indian J Dent Res. 2019 Nov-Dec;30(6):834-838.Pubmed PMID: 31939356.

[29]. Auswin MK, Ramesh S. Knowledge, attitude, and practice survey on the use of dental operating microscope in endodontics: A cross-sectional survey. Pharm. Educ. Res. 2017;7(3).

[30]. Reeh ES, Messer HH, Douglas WH. Reduction in tooth stiffness as a result of endodontic and restorative procedures. J Endod. 1989 Nov 1;15(11):5126.

[31]. Wolters WJ, Duncan HF, Tomson PL, Karim IE, McKenna G, Dorri M,et al. Minimally invasive endodontics: a new diagnostic system for assessing pulpitis and subsequent treatment needs. Int Endod J. 2017 Sep;50(9):825829.Pubmed PMID: 28776717.

[32]. Asgary S, Eghbal MJ, Fazlyab M, Baghban AA, Ghoddusi J. Five-year results of vital pulp therapy in permanent molars with irreversible pulpitis: a noninferiority multicenter randomized clinical trial. Clin Oral Investig. 2015 Mar;19(2):335-41.Pubmed PMID: 24771228.

[33]. Ricucci D, Loghin S, Siqueira Jr JF. Correlation between clinical and histologic pulp diagnoses. J Endod. 2014 Dec 1;40(12):1932-9.

[34]. Simon S, Perard M, Zanini M, Smith AJ, Charpentier E, Djole SX, et al. Should pulp chamber pulpotomy be seen as a permanent treatment? Some preliminary thoughts. Int Endod J. 2013 Jan;46(1):79-87.Pubmed PMID: 22900881.

[35]. van der Sluis L, Kidd E, Gruythuysen R, Peters L. Preventive endodonticsan argument for avoiding root canal treatment. ENDO (Lond Engl). 2013 Dec 1;7(4):259-74.

[36]. Alqaderi H, Lee CT, Borzangy S, Pagonis TC. Coronal pulpotomy for cariously exposed permanent posterior teeth with closed apices: A systematic review and meta-analysis. J Dent. 2016 Jan;44:1-7.Pubmed PMID: 26687672.

[37]. Matsuo T, Nakanishi T, Shimizu H, Ebisu S. A clinical study of direct pulp capping applied to carious-exposed pulps. J Endod. 1996 Oct;22(10):551-6. Pubmed PMID: 9198445.

[38]. Helfer AR, Melnick S, Schilder H. Determination of the moisture content of vital and pulpless teeth. Oral Surg Oral Med Oral Pathol. 1972 Oct 1;34(4):661-70.

[39]. Papa J, Cain C, Messer HH. Moisture content of vital vs endodontically treated teeth. Endod Dent Traumatol. 1994 Apr;10(2):91-3.Pubmed 
PMID: 8062814.

[40]. Clark D, Khademi J, Herbranson E. The new science of strong endo teeth. Dent Today. 2013 Apr;32(4):112, 114, 116-7.Pubmed PMID: 23659101.

[41]. Clark D, Khademi J. Modern molar endodontic access and directed dentin conservation. Dent Clin North Am. 2010 Apr 1;54(2):249-73.

[42]. Plotino G, Grande NM, Isufi A, Ioppolo P, Pedullà E, Bedini R, et al. Fracture strength of endodontically treated teeth with different access cavity designs. J Endod. 2017 Jun 1;43(6):995-1000.

[43]. Krishan R, Paqué F, Ossareh A, Kishen A, Dao T, Friedman S. Impacts of conservative endodontic cavity on root canal instrumentation efficacy and resistance to fracture assessed in incisors, premolars, and molars. J Endod. 2014 Aug;40(8):1160-6.Pubmed PMID: 25069925.

[44]. Alovisi M, Pasqualini D, Musso E, Bobbio E, Giuliano C, Mancino D, et al. Influence of Contracted Endodontic Access on Root Canal Geometry: An In Vitro Study. J Endod. 2018 Apr;44(4):614-620.Pubmed PMID: 29336881.

[45]. Moore B, Verdelis K, Kishen A, Dao T, Friedman S. Impacts of Contracted Endodontic Cavities on Instrumentation Efficacy and Biomechanical Responses in Maxillary Molars. J Endod. 2016 Dec;42(12):1779-1783.Pubmed PMID: 27871481

[46]. Saygili G, Uysal B, Omar B, Ertas ET, Ertas H. Evaluation of relationship between endodontic access cavity types and secondary mesiobuccal canal detection. BMC Oral Health. 2018 Jul 6;18(1):121.Pubmed PMID: 29980211.

[47]. Özyürek T, Ülker Ö, Demiryürek EÖ, Yılmaz F. The Effects of Endodontic Access Cavity Preparation Design on the Fracture Strength of Endodontically Treated Teeth: Traditional Versus Conservative Preparation. J Endod. 2018 May;44(5):800-805.Pubmed PMID: 29571907.

[48]. Makati D, Shah NC, Brave D, Singh Rathore VP, Bhadra D, Dedania MS. Evaluation of remaining dentin thickness and fracture resistance of conventional and conservative access and biomechanical preparation in molars using cone-beam computed tomography: An in vitro study. J Conserv Dent. 2018 May-Jun;21(3):324-327.Pubmed PMID: 29899638.

[49]. Connert T, Zehnder MS, Amato M, Weiger R, Kühl S, Krastl G. Microguided Endodontics: a method to achieve minimally invasive access cavity preparation and root canal location in mandibular incisors using a novel computer-guided technique. Int Endod J. 2018 Feb;51(2):247-255.Pubmed PMID: 28665514

[50]. Siddique R, Nivedhitha MS. Effectiveness of rotary and reciprocating systems on microbial reduction: A systematic review. J Conserv Dent. 2019 Mar;22(2):114-22.

[51]. Govindaraju L, Neelakantan P, Gutmann JL. Effect of root canal irrigating solutions on the compressive strength of tricalcium silicate cements. Clin Oral Investig. 2017 Mar;21(2):567-571.Pubmed PMID: 27469101.

[52]. Siddique R, Sureshbabu NM, Somasundaram J, Jacob B, Selvam D. Qualitative and quantitative analysis of precipitate formation following interaction of chlorhexidine with sodium hypochlorite, neem, and tulsi. J Conserv Dent. 2019 Jan-Feb;22(1):40-47.Pubmed PMID: 30820081.

[53]. Siddique R, Nivedhitha MS, Jacob B. Quantitative analysis for detection of toxic elements in various irrigants, their combination (precipitate), and para-chloroaniline: An inductively coupled plasma mass spectrometry study. J Conserv Dent. 2019 Jul-Aug;22(4):344-350.Pubmed PMID: 31802817.

[54]. Manohar MP, Sharma S. A survey of the knowledge, attitude, and awareness about the principal choice of intracanal medicaments among the general dental practitioners and nonendodontic specialists. Indian J Dent Res. 2018 Nov-Dec;29(6):716-720.Pubmed PMID: 30588997

[55]. Coldero LG, McHugh S, MacKenzie D, Saunders WP. Reduction in intracanal bacteria during root canal preparation with and without apical enlargement. Int Endod J. 2002 May;35(5):437-46.

[56]. Boutsioukis C, Gogos C, Verhaagen B, Versluis M, Kastrinakis E, Van der
Sluis LW. The effect of apical preparation size on irrigant flow in root canals evaluated using an unsteady Computational Fluid Dynamics model. Int Endod J. 2010 Oct;43(10):874-81.

[57]. Khademi A, Yazdizadeh M, Feizianfard M. Determination of the minimum instrumentation size for penetration of irrigants to the apical third of root canal systems. J Endod. 2006 May;32(5):417-20.Pubmed PMID: 16631839.

[58]. Metzger $Z$. The self-adjusting file (SAF) system: An evidence-based update. J Conserv Dent. 2014 Sep;17(5):401-19.Pubmed PMID: 25298639

[59]. Paqué F, Barbakow F, Peters OA. Root canal preparation with Endo-Eze AET: changes in root canal shape assessed by micro-computed tomography. Int Endod J. 2005 Jul;38(7):456-64.

[60]. Gu LS, Kim JR, Ling J, Choi KK, Pashley DH, Tay FR. Review of contemporary irrigant agitation techniques and devices. J Endod. 2009 Jun 1;35(6):791-804.

[61]. Ruddle CJ. Endodontic Triad for Success: The Role of Minimally Invasive Technology. Dent Today. 2015 May;34(5):76, 78-80.Pubmed PMID: 26470575.

[62]. Mamoun JS. On the ferrule effect and the biomechanical stability of teeth restored with cores, posts, and crowns. Eur J Dent. 2014 Apr;8(2):281-286. Pubmed PMID: 24966784.

[63]. Carr GB, Murgel CA. The use of the operating microscope in endodontics. Dent. Clin. N. Am. 2010 Apr 1;54(2):191-214.

[64]. Vijayashree Priyadharsini J. In silico validation of the non-antibiotic drugs acetaminophen and ibuprofen as antibacterial agents against red complex pathogens. J Periodontol. 2019 Dec;90(12):1441-1448.PubmedPMID: 31257588.

[65]. Pc J, Marimuthu T, Devadoss P, Kumar SM. Prevalence and measurement of anterior loop of the mandibular canal using CBCT: A cross sectional study. Clin Implant Dent Relat Res. 2018 Apr 6;20(4):531-4.

[66]. Ramesh A, Varghese S, Jayakumar ND, Malaiappan S. Comparative estimation of sulfiredoxin levels between chronic periodontitis and healthy patients - A case-control study. J Periodontol. 2018 Oct;89(10):1241-1248.Pubmed PMID: 30044495.

[67]. Ramadurai N, Gurunathan D, Samuel AV, Subramanian E, Rodrigues SJ. Effectiveness of $2 \%$ Articaine as an anesthetic agent in children: randomized controlled trial. Clin Oral Investig. 2019 Sep;23(9):3543-50.

[68]. Sridharan G, Ramani P, Patankar S, Vijayaraghavan R. Evaluation of salivary metabolomics in oral leukoplakia and oral squamous cell carcinoma. J Oral Pathol Med. 2019 Apr;48(4):299-306.

[69]. Mathew MG, Samuel SR, Soni AJ, Roopa KB. Evaluation of adhesion of Streptococcus mutans, plaque accumulation on zirconia and stainless steel crowns, and surrounding gingival inflammation in primary molars: randomized controlled trial. Clin Oral Investig. 2020 Sep;24(9):1-6.Pubmed PMID: 31955271

[70]. Samuel SR. Can 5-year-olds sensibly self-report the impact of developmental enamel defects on their quality of life? Int J Paediatr Dent. 2021 Mar;31(2):285-286.Pubmed PMID: 32416620.

[71]. R H, Ramani P, Ramanathan A, R JM, S G, Ramasubramanian A, et al. CYP2 C9 polymorphism among patients with oral squamous cell carcinoma and its role in altering the metabolism of benzo[a]pyrene. Oral Surg Oral Med Oral Pathol Oral Radiol. 2020 Sep;130(3):306-312.Pubmed PMID: 32773350 .

[72]. Chandrasekar R, Chandrasekhar S, Sundari KKS, Ravi P. Development and validation of a formula for objective assessment of cervical vertebral bone age. Prog Orthod. 2020 Oct 12;21(1):38.Pubmed PMID: 33043408.

[73]. Vijayashree Priyadharsini J, Smiline Girija AS, Paramasivam A. In silico analysis of virulence genes in an emerging dental pathogen A. baumannii and related species. Arch Oral Biol. 2018 Oct;94:93-98.Pubmed PMID: 30015217. 